\title{
Pengaruh Kepemilikan Saham, Keputusan Pendanaan, CSR dan Kinerja Keuangan terhadap Nilai Perusahaan Jasa Konstruksi
}

\author{
Harsana $^{1}$, Meina Wulansari Yusniar ${ }^{2}$, Asrid Juniar \\ ${ }^{123}$ Universitas Lambung Mangkurat \\ Email : harsana@gmail.com
}

\begin{abstract}
This study aims to examine and analyze the effect of Managerial Ownership (X1), Institutional Ownership (X2), Financing Decision (X3), CSR (X4) and Financial Performance (X5) as independent variables either partially or simultaneously on Firm Value $(Y)$ as the dependent variable in the Construction Services companies Listed on the Stock Exchange in 2014 - 2018. The method of this research used secondary data from the annual report 2014 to 2018 period in the study sample as many as 10 companies. Assessment of the effect of independent variables on the dependent variable used a multiple linear regression analysis with SPSS Ver. 25.

The results of this study concluded that there is a significant negative effect of managerial ownership and institutional ownership on firm value. The financing decision is a significant positive effect on firm value. Meanwhile, both CSR and financial performance has no significant effect on firm value. Simultaneously, the independent variables can sufficiently explain the variation value of the company with $58.8 \%$ coefficient of determination.
\end{abstract}

Keywords: Stock Ownership, Financing Decision, CSR, Financial Performance and Firm Value

Abstrak

Penelitian ini bertujuan untuk menguji dan menganalisis pengaruh Kepemilikan Manajerial $\left(\mathrm{X}_{1}\right)$, Kepemilikan Institusional $\left(\mathrm{X}_{2}\right)$, Keputusan Pendanaan $\left(\mathrm{X}_{3}\right)$, CSR $\left(\mathrm{X}_{4}\right)$ dan Kinerja Keuangan $\left(\mathrm{X}_{5}\right)$ sebagai variabel independen baik secara parsial maupun simultan terhadap Nilai Perusahaan (Y) sebagai variabel dependen pada Perusahaan Jasa Konstruksi yang Terdaftar di BEI 2014 - 2018. Metode penelitian ini menggunakan data sekunder berupa laporan tahunan periode 2014 sampai dengan 2018 pada sampel penelitian sebanyak 10 perusahaan. Pengujian pengaruh variabel independen terhadap variabel dependen menggunakan teknik analisis regresi linier berganda dengan SPSS Ver. 25.

Hasil penelitian ini menyimpulkan bahwa terdapat pengaruh negatif signifikan kepemilikan manajerial dan kepemilikan institusional terhadap nilai perusahaan. Keputusan pendanaan berpengaruh positif secara signifikan terhadap nilai perusahaan. Sedangkan, baik CSR maupun kinerja keuangan tidak berpengaruh signifikan terhadap nilai perusahaan. Secara simultan, variabel independen cukup dapat menjelaskan variasi nilai perusahaan dengan besaran koefisien determinasi $58,8 \%$.

Kata Kunci : Kepemilikan Saham, Keputusan Pendanaan, CSR, Kinerja Keuangan dan Nilai Perusahaan

(C) 2020 Jurnal Riset Inspirasi Manajemen dan Kewirausahaan

\section{PENDAHULUAN}

Global Competitiveness Index tahun 2017 2018 bahwa pada saat ini Indonesia berada di urutan ke - 36 dari 137 negara. The Global Competitiveness Index merupakan salah satu indikator untuk mengukur daya saing nasional yang meliputi 137 negara, dimana tolok ukurnya didefinisikan melalui seperangkat institusi, kebijakan, dan faktor yang menentukan tingkat produktivitas. Indonesia berada di rangking 36 maka harus berusaha agar dapat mewujudkan misi bangsa yang berdaya saing tinggi. Salah satu tantangan besar yang akan dihadapi adalah strategi mencapai tingkat pertumbuhan ekonomi yang tinggi, berkelanjutan, dan inklusif serta tetap memperhatikan kestabilan ekonomi. Maka perlu adanya optimalisasi seluruh potensi ekonomi yang ada melalui pelaksanaan pembangunan yang berkelanjutan dan efektif.

Pemerintah harus mengambil kebijakankebijakan konkret dalam upaya meningkatkan pertumbuhan ekonomi agar memacu masyarakat untuk bisa memperoleh lapangan pekerjaan dan pengembangan sektor industri yang mempunyai rantai distribusi yang panjang. Sektor konstruksi 
menjadi salah satu lapangan usaha yang mencetak peningkatan kinerja positif di tengah pertumbuhan ekonomi yang melambat. Sektor konstruksi harus ditingkatkan dengan cara pembangunan infrastruktur, sehingga akan menyerap lapangan kerja yang besar dan menarik industri-industri supporting lainnya ikut berkembang. Infastruktur yang dibangun dengan kualitas baik akan mendorong suatu daerah dengan daerah lain terhubung dengan cepat, suplai distribusi dari daerah industri ke seluruh daerah menjadi lancar, efektif sehingga akan menekan biaya produksi. Hal ini merupakan salah satu cara paling efektif agar percepatan ekonomi indonesia berkembang pesat dan dapat sejajar dengan negara-negara maju lainnya.

Pada Bulan Januari 2016 telah diterbitkan kebijakan strategis pemerintah melalui Peraturan Presiden No. 3 tahun 2016 tentang Percepatan Pelaksanaan Proyek Strategis Nasional dan Instruksi Presiden No. 6 tahun 2016 tentang Percepatan Proyek Strategis Nasional. Kebijakan strategis pemerintah tentang pembangunan infrastruktur memberikan dorongan yang kuat pada pertumbuhan dan persaingan bisnis di Jasa Konstruksi. Beberapa perusahaan jasa konstruksi BUMN dan swasta meresponnya dengan melakukan diversifikasi usaha, salah satunya dengan mendirikan anak perusahaan di sektor bisnis hulu sampai dengan hillir untuk mendukung/menopang keunggulan dan keberlanjutan bisnis utamanya (Core Business). Anak perusahaan tersebut dibentuk untuk menciptakan kontrak pekerjaan dengan melakukan investasi pendanaan dikarenakan adanya masalah keterbatasan APBN dalam mencukupi pembiayaan infrastruktur. Maupun permasalahan disisi lain dimana perusahaan induk membutuhkan suplay material / alat yang besar dan spesifik, namun terkendala keterbatasan kemampuan perusahaan supporting yang ada sehingga dibentuklah anak perusahaan yang bergerak di bidang supporting pada bisnis utamanya tersebut. Bahwa dengan adanya kebijakan strategis pemerintah tentang pembangunan infrastruktur dan berimbas langsung pada dunia konstruksi tentunya akan meningkatkan nilai perusahaan, namun berdasarkan Gambar 1 justru terjadi anomali tentang tren harga saham yang mengalami penurunan pada sektor 6 (Property, Real Estate and Building Construction).

Ada tiga masalah utama yang dihadapi oleh para pengusaha yang bergerak di bidang jasa kontruksi yaitu tidak stabilnya harga bahan bangunan, permintaan yang fluktuatif atau perolehan kontrak pekerjaan yang fluktuatif baik dilihat dari segi waktu maupun nilainya, serta tingkat persaingan yang tinggi. Harga bahan bangunan sangat menentukan nilai suatu kontrak pekerjaan. Bila harga bahan bangunan tidak stabil akan berpotensi memberikan dampak kerugian kontraktor karena rentang waktu antara penetapan kontrak dan pelaksanaan pekerjaan berbeda (Badan Pusat Statistik, 2018).

\section{Gambar 1 \\ Rata-rata Harga Saham per Sektor di BEI Periode 2017 - 2018}

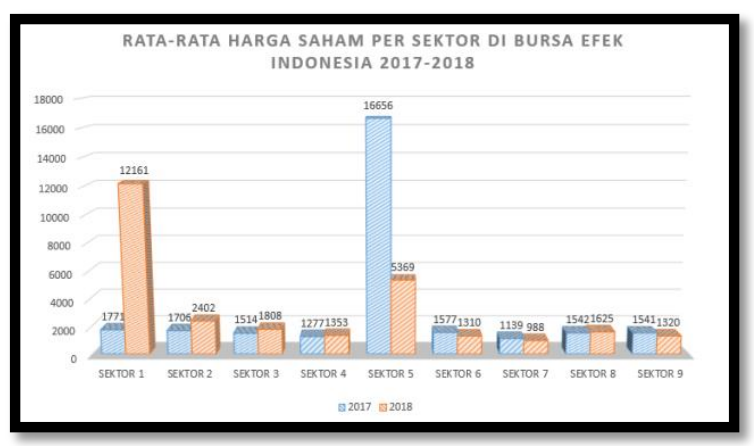

Sumber : Fact Book 2017-2018 www.idx.co.id (Data diolah 2019)

\section{Gambar 1 \\ Rata-rata Harga Saham per Sektor di BEI Periode 2017 - 2018}

Jumlah perusahaan jasa konstruksi yang terdaftar di BEI masih begitu minim, bahkan kapitalisasi pasar (market capitalization) yang besar masih di dominasi oleh perusahaan BUMN. Hal ini dikarenakan bahwa perusahaan jasa konstruksi banyak menghadapi tantangan risiko yang tinggi, sehingga perusahaan swasta harus mengambil strategis keputusan yang tepat untuk bisa bersaing dalam dunia konstruksi. Risiko yang dihadapi diantaranya : modal yang besar karena harus membiayai proyek didepan terutama untuk proyek yang kontraknya turn key, perputaran uang yang besar dan cepat karena rentang waktu pekerjaan yang pendek, kontrak pekerjaan dengan nilai tetap pada produk yang belum pasti, serta masalah - masalah ekonomi, politik dan sosial yang ikut mempengaruhi kinerja perusahaan.

Kebijakan pemerintah tentang percepatan pembangunan infrastruktur yang membutuhkan biaya sangat besar dan tidak diimbangi oleh kesiapan pendanaan dari APBN, sehingga memberikan peluang perusahaan untuk menjadi investor dalam pembiayaan pembangunan dengan kompensasi kontrak turn key atau masa konsesi untuk pengoperasionalan produk infrastuktur tersebut. Peluang ini banyak diambil oleh 
perusahaan-perusahaan BUMN, karena disamping sebagai agen pembangunan negara, perusahaan BUMN juga mempunyai aset yang lebih besar dibanding perusahaan swasta sehingga mereka bisa lebih mudah melakukan pembiayaan proyek didepan atau ivestasi pembiayaan dengan jaminan masa konsesi. Permasalahan yang dihadapi jasa konstruksi sangat berdampak pada kondisi operasional perusahaan yang akan mempengaruhi penilaian investor terhadap nilai perusahaan. Perusahaan yang bergerak dibidang jasa konstruksi perlu memperhatikan faktor-faktor yang mampu meningkatkan nilai perusahaan agar mampu mengimbangi perkembangan industri, pertumbuhan ekonomi maupun dalam menghadapi persaingan. Nilai perusahaan merupakan gambaran dari kesejahteraan pemegang saham, dimana harga saham salah satu cerminan dari nilai perusahaan. Nilai perusahaan yang tinggi akan membuat pasar atau investor percaya pada kinerja perusahaan dan prospek perusahaan di masa depan. Optimalisasi nilai perusahaan merupakan tujuan perusahaan dapat dicapai melalui pelaksanaan fungsi manajemen keuangan, dimana satu keputusan keuangan yang diambil akan mempengaruhi keputusan keuangan lainnya dan berdampak pada nilai perusahaan (Fama dan French, 1998).

Kepemilikan merupakan salah satu faktor internal perusahaan guna mencapai kemajuan perusahaan. Apabila pemegang saham semakin terlibat dan semakin terkonsentrasinya kepemilikan, maka semakin besar juga kekuatan pemegang saham dalam mempengaruhi perusahaan. Faktor kedua yang mempengaruhi nilai perusahaan adalah kepemilikan institusional. . Kepemilikan institusional merupakan satu alat yang dapat digunakan untuk mengurangi agency conflict. Faktor ketiga yang mempengaruhi nilai perusahaan adalah keputusan pendanaan. Keown et al., (2010:121), mengemukakan bahwa kebijakan utang adalah kebijakan yang dilakukan perusahaan untuk mendanai operasinya dengan menggunakan utang keuangan atau yang biasa disebut dengan financial leverage atau leverage keuangan. Faktor keempat yang juga mempengaruhi nilai perusahaan adalah pelaksanaan Corporate Social Responsibility (CSR) yang merupakan suatu usaha yang dilakukan oleh perusahaan guna menyeimbangkan antara aspek ekonomi, social, dan lingkungan. CSR pertama kali disebutkan dalam sebuah literatur Bowen (1953) yang mendefinisikan sebagai tindakan pilantropis yang mengacu pada nilai-nilai sosial. CSR memiliki karakteristik berupa tindakan sukarela artinya perusahaan tidak dituntut atau diwajibkan untuk melakukan CSR. Faktor kelima yaitu kinerja keuangan juga sangat penting, bahwa nilai perusahaan dipengaruhi pula oleh kinerja keuangan perusahaan. Menurut Fahmi (2011:2) kinerja keuangan adalah suatu analisis yang dilakukan untuk melihat sejauh mana suatu perusahaan telah melaksanakan dengan menggunakan aturan-aturan pelaksanaan keuangan secara baik dan benar. Berdasarkan uraian diatas, maka Peneliti tertarik untuk melakukan penelitian dengan judul "Pengaruh Kepemilikan Saham, Keputusan Pendanaan, CSR dan Kinerja Keuangan terhadap Nilai Perusahaan Jasa Konstruksi” yang terdaftar di BEI 2014-2018.

\section{KAJIAN LITERATUR}

\section{Signalling Theory}

Kondisi - kondisi yang terjadi maupun juga kebijakan yang diambil oleh perusahaan akan memberikan sebuah pertanda bagi investor. Hal tersebut yang memberikan persepsi positif atau negatif dalam keputusan menanamkan modal. Mengejar keuntungan sebagai tujuan perusahaan, diharapkan informasi yang disampaikan adalah sesuatu yang baik atau prospek yang menjanjikan (Hanafi, 2013).

\section{Stakeholder Theory}

Perusahaan sebagai kesatuan organisasi disokong oleh individu yang banyak bukan hanya sendiri (Freeman \& Reed, 1983). Secara bersamasama individu tentunya ingin mencapai kesejahteraan. Dengan demikian, siapapun yang terlibat dalam lingkup organisasi atau perusahan, informasi menjadi suatu keharusan dipenuhi. Baik atau buruk sebuah kabar harus disampaikan karena hal itu wajib hukumnya .

\section{Legitimasi Theory}

Lingkungan tidaknya tentang yang terlibat langsung tetapi juga hal yang tidak terlibat secara langsung. Publik adalah bagian yang tidak terkait secara langsung pada kegiatan perusahaan, tapi teori ini menyampaikan bahwa publik mendapatkan efek secara tidak langsung akibat aktivitas perusahaan. Banyak sekali dalam pembahasan lingkungan dan sosial yang menerangkan tentang hal demikian (Ulum, 2009).

\section{Agency Theory}

Jensen dan Meckling (1976) menguraikan bahwa adanya kencurangan oleh manajer dalam menjalankan peran gandanya baik sebagai manajer perusahaan maupun sebagai pribadi yang ingin memperkaya diri. Manajer dapat membagi-bagi informasi namun bisa juga menyimpannya untuk keuntungan pridabi. Ketika pihak penyedia modal 
mengetahui kesenjangan itu, maka masalah sangat sering dipicu.

\section{Kepemilikan Saham}

Saham yang berupa surat berharga biasanya dikeluarkan oleh perusahaan agar mendapatkan dana yang bersumber di luar dar modal sediri. Banyak manfaatnya seperti mendukung perluasan usaha dan membantu membeli barang-barang modal lebih banyak di luar kemampuan perusahaan. Hanya saja, dengan keputusan tersebut perusahaan akhirnya tidak bisa memiliki seutuhnya terhadap usahanya tapi sudah terbagi dengan yang memiliki saham tersebut. Saham bisa dimiliki individu, kelompok masyakat bahkan manajer perusahaan sendiri (Jensen and Meckling, 1976).

\section{Keputusan Pendanaan}

Tugas perusahaan dalam menjalankan aktivitasnya tidak hanya berputar pada keuntungan, tapi bagaimana aktivitas tersebut dalam dijalankan. Dana sebagai bahan bakar dalam berjalannya roda usaha, namun pertanyaan yang sulit dijawab bagaimana komposisi paling tepat untuk keputusan pendanaan perusahaan. Haruskan perusahaan hanya didanai sendiri atau pihak luar. Menurut Martono dan Harjito (2010), pembahasan keputusan pendanaan mencakup beberapa hal diantaranya dari sekian banyak yaitu mengenai penetapan sumber dana yang diperlukan untuk membiayai investasi.

\section{CSR}

Sebelumnya, perusahaan hanya berfokus dengan usaha-usaha yang mampu memaksimalkan laba ataupun pundi-pundi keuntungan, kewajiban yang dimiliki pada sekitar internal saja. Namun, semakin majunya perekonomian yang sudah menghadapi era globalisasi, kewajiban atas usaha semakin meluas. Seperti yang telah didefinisikan ISO 26000 bahwa perusahaan memiliki tanggung jawab terhadap dampak-dampak dari keputusan yang diolah berkaitan kegiatan perusahaan kepada masyarakat dan lingkungan. Kewajiban tersebut dilakukan dengan melaksanakan yang namanya transparansi dan etika yang berkelanjutan. Banyak pihak yang masih memadang sebelah mata bahwa menjalankan kewajiban ini hanya memberikan beban bagi perusahaan, namun di lain sisi banyak juga yang memandang optimis bahwa dapat memberikan feedback yang baik seperti contohnya citra perusahaan yang baik yang dalam ilmu manajemen keuangan lebih sering disebut dengan nilai perusahaan.

\section{Kinerja Keuangan}

Segala input yang ada diperusahaan baik berupa SDM, teknologi dan modal diolah menghasilkan output berupa keuntungan bagi perusahaan. Baik atau buruknya ditentukan bagaimana kinerja perusahaan sendiri. Kinerja keuangan sebagai bagian kinerja perusahaan menjadi cerminan mengenai kondisi keuangan (Fahmi, 2011). Jika baik kinerjanya, maka berbanding lurus, ataupun sebaliknya. Untuk menilai sebuah kinerja keuangan, dilakukan pengukuran terhadap rasio - rasio keuangan dengan pengamatan dalam rentang periode tertentu.

\section{Nilai Perusahaan}

Persepsi yang ada dibenak para pemilik dana berlebih dipahami sebagai nilai perusahaan (Harmono, 2014). Yang mana seringkali dikaitkan dengan harga saham yang dimiliki perusahaan. Tinggi harga maka nilai perusahaan juga tinggi, nilai perusahaan yang rendah karena harga saham yang rendah pula. Dalam praktik nyatanya, banyak sekali bentuk representatif dari nilai perusahaan misalnya rasio keuangan salah satunya price to earning ratio.

Adapun hipotesis yang diuji sebagai berikut:

$\mathrm{H1}$ : Kepemilikan Saham Manajerial $\left(\mathrm{X}_{1}\right)$ berpengaruh terhadap Nilai Perusahaan (Y) Hipotesis Alternatif

$\mathrm{H} 2$ : Kepemilikan Saham Institusional $\left(\mathrm{X}_{2}\right)$ berpengaruh terhadap Nilai Perusahaan (Y) Hipotesis Alternatif

H3 : Keputusan Pendanaan $\left(\mathrm{X}_{3}\right)$ berpengaruh signifikan terhadap Nilai Perusahaan (Y) Hipotesis Alternatif

$\mathrm{H} 4$ : CSR $\left(\mathrm{X}_{4}\right)$ tidak berpengaruh signifikan terhadap Nilai Perusahaan (Y) - Hipotesis Nol H5 : Kinerja Keuangan $\left(\mathrm{X}_{5}\right)$ berpengaruh signifikan terhadap Nilai Perusahaan (Y) - Hipotesis Alternatif

\section{Gambar 2}

Kerangka Konseptual

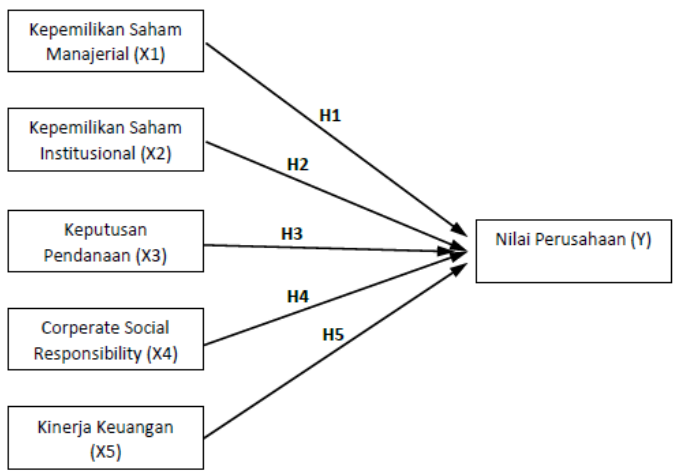




\section{METODE PENELITIAN}

Penelitian ini juga menggunakan penelitian yang bersifat causal, dengan tujuan untuk menjelaskan hubungan sebab-akibat antara dua variabel atau lebih melalui pengujian hipotesis. Populasi dalam penelitian ini adalah 16 perusahaan jasa kontruksi yang terdaftar di BEI tahun 20142018. Sampling purposive merupakan teknik penentuan sampel dengan pertimbangan tertentu (Thoifah, 2015). Sampel pada penelitian ini diambil dengan kriteria-kriteria sebagai berikut, yaitu: Perusahaan yang diambil sebagai sampel penelitian adalah perusahaan yang aktif pada Bursa Efek Indonesia setidaknya lima tahun berturut-turut yaitu pada tahun 2014-2018. Kriteria ini bertujuan untuk mengeliminiasi perusahaan yang melakukan listing dan delisting. Serta, Kelengkapan data pada perusahaan yang menjadi sampel (yang telah memenuhi kriteria pertama) berupa laporan tahunan periode 2014 - 2018.

Tabel 1

Penentuan Jumlah Sampel Penelitian

\begin{tabular}{|c|c|c|c|}
\hline 1) & $\begin{array}{l}\text { Perusahaan yang terdaftar di } \\
\text { Bursa Efek Indonesia selama } \\
\text { tahun } 2014-2018\end{array}$ & : & 16 \\
\hline 2) & $\begin{array}{l}\text { Perusahaan yang terdaftar di } \\
\text { Bursa Efek Indonesia yang } \\
\text { melakukan listing atau delisting } \\
\text { selama tahun 2014-2018. }\end{array}$ & : & (6) \\
\hline 3) & $\begin{array}{l}\text { Perusahaan yang tidak lengkap } \\
\text { terkait data yang diperlukan } \\
\text { dalam Penelitian ini yaitu berupa } \\
\text { laporan keuangan tahun 2014- } \\
2018\end{array}$ & : & (0) \\
\hline \multicolumn{2}{|c|}{$\begin{array}{l}\text { Jumlah perusahaan yang memenuhi } \\
\text { kriteria sebanyak }\end{array}$} & & 10 \\
\hline
\end{tabular}

Berdasarkan kriteria-kriteria tersebut, maka jumlah sampel penelitian yang telah memenuhi kriteria dalam penelitian ini sebanyak 10 perusahaan jasa kosntruksi yang terdaftar di BEI periode 2014 - 2018. Skala adalah alat pengukur data yaitu sebuah continuum melalui mana sebuah variabel diukur sehingga memberikan sebuah rentang kemungkinan nilai dari pengukuran. Variabel-variabel penelitian diukur dengan skala berikut :
Tabel 2

Pengukuran Variabel

\begin{tabular}{lcl}
\hline \multicolumn{1}{c}{ Variabel } & DOV & Skala \\
\hline Variabel Independen & & \\
\hline Kepemilikan Saham & Kepemilikan Saham & Rasio \\
Manajerial $\left(\mathrm{X}_{1}\right)$ & Manajerial $(\%)$ & \\
Kepemilikan Saham & Kepemilikan Saham & Rasio \\
Institusional $\left(\mathrm{X}_{2}\right)$ & Institusional $(\%)$ & Rasio \\
Keputusan & Debt to Assets Ratio & Rasio \\
Pendanaan $\left(\mathrm{X}_{3}\right)$ & $(\mathrm{X})$ & Rasio \\
CSR $\left(\mathrm{X}_{4}\right)$ & GRI (Index) & \\
Kinerja Keuangan & Return on Equity & \\
$\left(\mathrm{X}_{5}\right)$ & $(\%)$ & \\
\hline Variabel Dependen & & \\
\hline Nilai Perusahaan & Price to Earning & Rasio \\
(Y) & Ratio $(\mathrm{X})$ & \\
\hline \multicolumn{2}{l}{ Sumber: Diolah dari hasil studi literatur (2019) } \\
\end{tabular}

Penelitian ini menggunakan analisis regresi linier berganda yang pada dasarnya adalah studi mengenai ketergantungan variabel dependen (terikat) dengan satu atau lebih variabel independen (bebas), dengan tujuan untuk mengestimasi dan atau memprediksi rata-rata populasi atau nilai rata-rata variabel independen yang diketahui (Gujarati, 2003). Persamaan regresi dalam penelitian ini dapat dijelaskan sebagai berikut:

$$
Y=\alpha+b_{1} X_{1}+b_{2} X_{2}+b_{3} X_{3}+b_{4} X_{4}+b_{5} X_{5}+e
$$

Keterangan:

$\begin{array}{ll}\mathrm{Y} & : \text { Nilai Perusahaan } \\ \alpha & : \text { Konstanta } \\ \mathrm{b}_{1}, \mathrm{~b}_{2}, \mathrm{~b}_{3}, \mathrm{~b}_{4}, \mathrm{~b}_{5} & : \text { Koefisien regresi masing-masing } \\ & \text { variabel independen } \\ \mathrm{X}_{1} & : \text { Kepemilikan Saham Manajerial } \\ \mathrm{X}_{2} & : \text { Kepemilikan Saham Institusional } \\ \mathrm{X}_{3} & : \text { Keputusan Pendanaan } \\ \mathrm{X}_{4} & : \text { CSR } \\ \mathrm{X}_{5} & : \text { Kinerja Keuangan } \\ \mathrm{e} & : \text { Error Estimate }\end{array}$

Analisis regresi linier berganda sebelum dilakukan harus memenuhi asumsi klasik yaitu Uji Normalitas, Uji Multikolinearitas, Uji Autokorelasi dan Uji Heteroskedastisitas. Dengan tahapan pengujian hipotesis yaitu :

a. Koefisien Determinasi, koefisien determinasi $\left(\mathrm{R}^{2}\right)$ pada intinya mengukur seberapa jauh kemampuan model dalam menerangkan variasi variabel dependen.

b. Uji Fit Model, pada pengujian secara simultan akan diuji pengaruh kedua variabel independen secara bersama-sama terhadap variabel dependen. 
https://ejurnal.stimi-bim.ac.id/index.php/JRIMK

c. Uji t, pengujian secara individual untuk melihat pengaruh masing-masing varaibel sebab terhadap variabel akibat.

\section{HASIL PENELITIAN DAN PEMBAHASAN}

\section{Hasil Uji Asumsi Klasik}

Pada Tabel 3, dapat diketahui bahwa model penelitian memenuhi asumsi klasik yaitu uji normalitas terpenuhi dengan angka sig. Kolmogorov-Smirnov sebesar 0,185 (sig. > 0,05), uji multikolinieritas terpenuhi pada 5 (lima) variabel independen memiliki nilai Tolerance $\leq$ 0,10 atau nilai VIF-nya $\geq 10$, uji autokorelasi terpenuhi dengan nilai DW sebesar 1,905 (berada pada -2 sampai +2) dan terakhir uji heteroskedastisitas terpenuhi dengan nilai sig. > 0,05 .

Tabel 3

Hasil Uji Asumsi Klasik

\begin{tabular}{|c|c|c|c|c|}
\hline Asumsi Klasik & \multicolumn{3}{|c|}{ Output SPSS } & Kriteria \\
\hline Normalitas & \multicolumn{3}{|c|}{0,185 (KS Test) } & $>0,05$ \\
\hline \multirow[t]{5}{*}{ Multikolinieritas } & $\mathrm{X} 1$ & Tol. 0,144 & VIF 6,942 & \multirow{5}{*}{$\begin{array}{c}\text { nilai Tolerance } \\
\leq 0,10 \text { atau } \\
\text { sama dengan } \\
\text { nilai } V I F \geq 10\end{array}$} \\
\hline & $\mathrm{X} 2$ & Tol. 0,140 & VIF 7,125 & \\
\hline & $\mathrm{X} 3$ & Tol. 0,639 & VIF 1,564 & \\
\hline & $\mathrm{X} 4$ & Tol. 0,775 & VIF 1,290 & \\
\hline & $\mathrm{X5}$ & Tol. 0,634 & VIF 1,578 & \\
\hline Autokorelasi & \multicolumn{3}{|c|}{ DW. 1,905} & -2 sampai +2 \\
\hline \multirow[t]{5}{*}{ Heteroskedastisitas } & $\mathrm{X} 1$ & \multirow{2}{*}{\multicolumn{2}{|c|}{$\begin{array}{l}0,648 \\
0,718\end{array}$}} & \multirow{5}{*}{$\begin{array}{c}>0,05 \\
\text { Uji Glejser }\end{array}$} \\
\hline & $\mathrm{X} 2$ & & & \\
\hline & X3 & \multicolumn{2}{|l|}{0,855} & \\
\hline & $\mathrm{X} 4$ & \multicolumn{2}{|l|}{0,609} & \\
\hline & $\times 5$ & \multicolumn{2}{|l|}{0,120} & \\
\hline
\end{tabular}

Sumber: data diolah (2019)

\section{Pengujian Hipotesis \\ Koefisien Determinasi}

Adjusted $R$ Square merupakan koefisien determinasi yang telah dikoreksi dengan jumlah variabel dan ukuran sampel sehingga dapat mengurangi unsur bias jika terjadi penambahan variabel maupun penambahan ukuran sampel. Adjusted $R$ Square sebesar 0,588 berarti variasi nilai perusahaan dapat dijelaskan oleh variasi kepemilikan manajerial, kepemilihan institusional, keputusan pendanaan, CSR index dan kinerja perusahaan sebesar 58,8\%. Sedangkan, sebesar $41,2 \%$ variasi nilai perusahaan dijelaskan oleh variabel-variabel diluar pengamatan penelitian. Sehingga, variabel Kepemilikan Manajerial $\left(X_{1}\right)$, Kepemilikan Institusional $\left(\mathrm{X}_{2}\right)$, Keputusan Pendanaan $\left(\mathrm{X}_{3}\right)$, CSR $\left(\mathrm{X}_{4}\right)$ serta variabel Kinerja Keuangan $\left(\mathrm{X}_{5}\right)$ memiliki tingkat pengaruh "Sedang" (interval koefisien 0,400 - 0,599) terhadap Nilai Perusahaan (Y). Berikut output SPSS Ver. 25 yang menunjukkan koefisien determinasi,
Tabel 4

Output Koefisien Determinasi

\begin{tabular}{ccccc}
\hline Model & $\mathrm{R}$ & $\begin{array}{c}\mathrm{R} \\
\text { Square }\end{array}$ & $\begin{array}{c}\text { Adjusted } \\
\mathrm{R} \\
\text { Square }\end{array}$ & $\begin{array}{c}\text { Std. } \\
\text { Error of } \\
\text { the } \\
\text { Estimate }\end{array}$ \\
\hline 1 & 0,794 & 0,631 & 0,588 & 0,68334 \\
\hline
\end{tabular}

Sumber : Data diolah, 2019

Uji F

Table 5

Output Uji Model Fit

\begin{tabular}{llrrccc}
\hline \multirow{2}{*}{ Model } & $\begin{array}{c}\text { Sum of } \\
\text { Squares }\end{array}$ & Df & $\begin{array}{c}\text { Mean } \\
\text { Square }\end{array}$ & F & Sig. \\
\hline 1 & Regression & 34,280 & 5 & 6,856 & 14,682 & 0,000 \\
& Residual & 20,079 & 43 & 0,467 & & \\
& Total & 54,358 & 8 & & & \\
\hline
\end{tabular}

Sumber : Data diolah, 2019

Berdasarkan Tabel 5.11, bahwa tingkat kesalahan atau probabilitas sebesar 0,000 atau lebih kecil dari 0,05. Variabel Kepemilikan Manajerial $\left(\mathrm{X}_{1}\right)$, Kepemilikan Institusional $\left(\mathrm{X}_{2}\right)$, Keputusan Pendanaan $\left(\mathrm{X}_{3}\right)$, CSR $\left(\mathrm{X}_{4}\right)$ serta variabel Kinerja Keuangan $\left(\mathrm{X}_{5}\right)$ secara simultan mampu menjelaskan perubahan variabel tergantung yaitu variabel Nilai Perusahaan (Y) atau model dinyatakan cocok atau fit. Model regresi yang dihasilkan dari pengujian, sebagai berikut.

$$
\begin{aligned}
& Y=\alpha+b_{1} X_{1}+b_{2} X_{2}+b_{3} X_{3}+b_{4} X_{4}+b_{5} X_{5}+\varepsilon \\
& Y=-0,011-1,803 X_{1}-1,990 X_{2}+0,300 X_{3}- \\
& 0,091 X_{4}-0,082 X_{5}
\end{aligned}
$$

\section{UJI t}

Secara parsial, variabel kepemilikan manajerial $\left(\mathrm{X}_{1}\right)$ menunjukkan angka signifikan sebesar $0,000<\alpha(0,05)$ dengan koefisien regresi 1,803 artinya kepemilikan manajerial $\left(\mathrm{X}_{1}\right)$ berpengaruh signifikan terhadap nilai perusahaan secara negatif atau H1/HIPOTESIS ALTERNATIF DITERIMA. Variabel kepemilikan institusional $\left(\mathrm{X}_{2}\right)$ menunjukkan angka signifikan sebesar 0,000 $<\alpha(0,05)$ dengan koefisien regresi $-1,990$ artinya kepemilikan institusional $\left(\mathrm{X}_{2}\right)$ berpengaruh signifikan terhadap nilai perusahaan secara negatif atau H2/HIPOTESIS ALTERNATIF DITERIMA. Variabel keputusan pendanaan $\left(\mathrm{X}_{3}\right)$ menunjukkan angka signifikan sebesar $0,013<\alpha(0,05)$ dengan koefisien regresi 0,300 artinya keputusan pendanaan $\left(\mathrm{X}_{3}\right)$ berpengaruh signifikan terhadap nilai perusahaan atau H3/HIPOTESIS ALTERNATIF DITERIMA. Variabel CSR index $\left(\mathrm{X}_{4}\right)$ menunjukkan angka signifikan sebesar 0,437 $>\alpha(0,05)$ dengan koefisien regresi -0,091 artinya 
CSR index $\left(\mathrm{X}_{4}\right)$ tidak berpengaruh signifikan terhadap nilai perusahaan atau H4/HIPOTESIS NOL DITERIMA. Terakhir, H5 DITOLAK atau Kinerja Keuangan tidak berpengaruh terhadap nilai perusahaan (Y), karena hasil menunjukkan angka signifikan sebesar $0,503>\alpha(0,05)$ dengan koefisien regresi $-0,082$. Hasil penelitian ini menunjukkan bahwa dari 5 (lima) hipotesis yang diuji, hanya 1 (hipotesis) yang tidak diterima.

Tabel 6

\section{Output Uji Parsial}

\begin{tabular}{|c|c|c|c|c|c|c|}
\hline & \multirow{2}{*}{ Model } & \multicolumn{2}{|c|}{$\begin{array}{l}\text { Unstandardized } \\
\text { Coefficients }\end{array}$} & \multirow{2}{*}{$\begin{array}{c}\begin{array}{c}\text { Standardized } \\
\text { Coefficients }\end{array} \\
\text { Beta }\end{array}$} & \multirow[b]{2}{*}{$\mathrm{t}$} & \multirow{2}{*}{ Sig. } \\
\hline & & B & $\begin{array}{l}\text { Std. } \\
\text { Error }\end{array}$ & & & \\
\hline \multirow[t]{6}{*}{1} & (Const.) & $-0,011$ & 0,098 & & $-0,114$ & 0,910 \\
\hline & $\mathrm{X} 1$ & $-1,803$ & 0,228 & $-1,929$ & $-7,899$ & 0,000 \\
\hline & $\mathrm{X} 2$ & $-1,990$ & 0,240 & $-2,051$ & $-8,292$ & 0,000 \\
\hline & $\mathrm{X} 3$ & 0,300 & 0,116 & 0,300 & 2,585 & 0,013 \\
\hline & $\mathrm{X} 4$ & $-0,091$ & 0,116 & $-0,083$ & $-0,784$ & 0,437 \\
\hline & X5 & $-0,082$ & 0,122 & 0,079 & $-0,675$ & 0,503 \\
\hline
\end{tabular}

\section{Implikasi Teoritis}

Penelitian ini mendukung teori keagenan yang mengasumsikan bahwa semua individu bertindak atas kepentingan mereka sendiri. Berdasarkan hasil analisis, bahwa kepemilikan manajerial maupun institusional berpengaruh negatif terhadap nilai perusahaan. Semakin besar kepemilikan manajerial dalam struktur pemegang saham, maka menyebabkan penurunan nilai perusahaan. Hal tersebut dikarenakan, adanya kerawanan akan tindakan yang lebih mengutamakan kepentingan manajer sendiri dan akhirnya cenderung opportunistic.

Adapun pada kepemilikan institusional yang harusnya berdampak positif karena dapat memberikan pengawasan aktif terhadap manajerial, dengan besarnya kepemilikan malah cenderung berpotensi untuk memprioritaskan kepentingan pribadi daripada kepentingan pemegang saham minoritas. Sehingga, dua hal tersebut direspon negatif secara signifikan oleh investor. Hal ini sejalan dengan penelitian Abdolkhani \& Jalali (2013) menyatakan bahwa peningkatan kepemilikan saham manajerial berdampak pada penurunan nilai perusahaan. Namun, tidak mendukung hasil dari penelitian yang dilakukan Dian \& Lidyah (2013) bahwa besarnya kepemilikan saham institusional memberikan dampak positif karena adanya pengawasan aktif terhadap kinerja perusahaan.

Keputusan pendanaan menjadi salah satu kebijakan perusahan yang memberikan sebuah informasi yang disampaikan oleh manajer ke pasar.
Jika manajer mempunyai keyakinan bahwa prospek perusahaan baik, dan karenanya ingin agar harga saham meningkat, ia ingin mengkomunikasikan hal tersebut ke investor. Di lain sisi, jumlah utang yang meningkat kemungkinan bangkrut akan semakin meningkat. Karena itu, perusahaan yang meningkatkan utang bisa dipandang sebagai perusahaan yang yakin dengan prospek perusahaan di masa mendatang. Karena cukup yakin, maka manajer perusahaan tersebut berani menggunakan utang yang lebih besar. Investor diharapkan akan menangkap signal tersebut, signal bahwa perusahaan mempunyai prospek yang baik. Dengan demikian utang merupakan tanda atau signal positif. Sinyal merupakan suatu tindakan yang diambil oleh manajemen perusahaan yang memberikan petunjuk kepada para investor mengenai bagaimana cara pandang manajemen terhadap prospek perusahaan.

Hasil penelitian mendukung teori sinyal atau Signalling Theory karena keputusan pendanaan berpengaruh positif signifikan terhadap nilai perusahaan. Hasil penelitian sesuai dengan penelitian yang telah dilakukan oleh Hardinis, dkk (2019) dan Aggarwal \& Padhan (2017), namun tidak mendukung hasil penelitian Manurung,dkk (2014) bahwa terdapat pengaruh negatif antara leverage dan nilai perusahaan (Kodongo,dkk, 2014). Selain keputusan pendanaan yang menginformasikan struktur modal perusahaan, adapun tingkat profitabilitas menjadi informasi yang penting bagi mengenai kinerja keuangan perusahaan terkait kemampuan perusahaan dalam menghasilkan laba selama periode tertentu yang dibandingkan dengan penggunaan aset atau ekuitas secara produktif. Menurut Rusmanto (2011:621) dalam Ridhawati (2014) pengukuran kinerja keuangan bertujuan untuk memberikan informasi yang berguna dalam keputusan penting mengenai aset yang digunakan dan untuk memacu para manajer membuat keputusan yang menyalurkan kepentingan perusahaan.

Namun, hasil penelitian ini menunjukkan bahwa kinerja keuangan perusahaan menjadi sinyal yang negatif hanya saja tidak signifikan terhadap nilai perusahaan. Hanya sebagian kecil investor mungkin yang menggunakan pengukuran kinerja keuangan sebagai dasar untuk menilai perubahan potensial sumber daya ekonomi untuk kemajuan perusahaan. Artinya, hasil penelitian ini tidak sejalan dengan penelitian yang dilakukan oleh Paminto, dkk (2016) dan Sabrin, dkk (2016) bahwa harga saham atau nilai perusahaan akan meningkat dengan sinyal positif kinerja keuangan perusahaan. 
Hasil penelitianpun tidak mendukung teori Stakeholder karena pada pengungkapan CSR yang mana seluruh stakeholder memiliki hak untuk disediakan informasi tentang bagaimana aktivitas organisasi mempengaruhi mereka, bahkan ketika mereka memilih untuk tidak menggunakan informasi tersebut dan bahkan ketika mereka tidak dapat secara langsung memainkan peran yang konstruktif dalam kelangsungan hidup (Deegan, 2004 (dalam Ulum 2009: 4)). Stakeholder atau lebih dikenal dengan istilah pemangku kepentingan adalah setiap kelompok atau individu yang dapat mempengaruhi atau dipengaruhi oleh pencapaian tujuan organisasi (Freeman \& Reed, 1983: 91).

Kelompok stakeholder terdiri dari pemegang saham, karyawan, pelanggan, pemasok, kreditor, pemerintah, dan masyarakat. Teori stakeholder secara tidak langsung memaksa manajemen perusahaan untuk mengelola secara maksimal seluruh potensi sumber daya yang dimilikinya (baik karyawan (human capital), aset fisik (capital employed), maupun structural capital) agar dapat menciptakan value added (nilai tambah) sekaligus mendorong peningkatan kinerja keuangan yang pada akhirnya dapat memberikan manfaat bagi seluruh stakeholder.

Mengacu pada CSR index yang sangat rendah pada 10 perusahaan sampel bisa jadi bahwa banyak aktivitas CSR tidak diungkapkan secara rinci ataupun aktivitas CSR yang tidak dilaksanakan tapi dilaporkan untuk memberikan kesan yang baik pada pelaporan tahunan. Namun, dapat dilihat bahwa beberapa perusahaan memang menunjukkan minat untuk terus memperbaiki dan meningkatkan pelaporan aktivitas CSR. Minimnya pengungkapan CSR juga mengindikasikan bahwa hasil penelitian juga tidak mendukung teori Legitimasi, dimana pada teori ini menempatkan persepsi dan pengakuan publik sebagai dorongan utama dalam melakukan pengungkapan suatu informasi didalam laporan keuangan, dengan menunjukan kapasitan intellectual capital atau dengan kata lain memperoleh legitimasi dari publik atas kekayaan intelektual yang dimiliki perusahaan. Dengan demikian, legitimasi merupakan manfaat atau sumber daya potensial bagi perusahaan untuk bertahan hidup (Hadi, 2011: 87). Penelitian ini mendukung hasil penelitian sebelumnya yaitu Horn, dkk (2018); Firdaus, dkk (2018) dan Haryono \& Iskandar (2015) bahwa pengungkapan CSR tidak memberikan pengaruh terhadap penilaian investor pada perusahaan.

\section{Implikasi Manajerial}

Perusahaan didirikan tentunya untuk memaksimalkan kemakmuran stakeholder baik pemegang saham atau pemilik modal, karyawan bahkan masyarakat melalui maksimalisasi nilai perusahaan. Pencapaian tujuan tersebut tentunya tidaklah mudah karena perusahaan akan menghadapi berbagai kendala apalagi telah menjadi perusahaan terbuka. Salah satunya adalah adanya konflik agensi antara pemilik modal dan manajer. Beberapa alternatif untuk mengendalikan konflik agensi diantaranya pengelolaan terhadap jumlah kepemilikan manajerial dan kepemilikan institusional. Menurut Jansen dan Meckling (1976) menyatakan bahwa semakin besar proporsi kepemilikan manajemen pada perusahaan akan dapat menyatukan kepentingan antara manajer dengan pemegang saham. Peningkatan jumlah kepemilikan manajerial mampu mengurangi potensi prilaku opportunistic dan peningkatan pengawasan melalui peningkatan jumlah peningkatan kepemilikan institusional. Namun, perlu diperhatikan bahwa perusahaan sangat penting memperhatikan proporsi atau persentase jumlah kepemilikan yang tepat karena dari hasil penelitian mengungkapkan sinyal yang negatif terhadap nilai perusahaan.

Selain proporsi jumlah kepemilikan saham, maksimalisasi nilai perusahaan juga dapat ditentukan melalui keputusan pendanaan. Keputusan pendanaan terkait penggunaan utang sebagai salah satu sumber modal perusahaan. Keputusan ini sangat penting karena mampu meningkatkan kesejahteraan perusahaan, di lain sisi kesalahan dalam menentukan keputusan pendanaan akan berdampak pada risiko financial distress yang membawa perusahaan pada kondisi kebangkrutan. Keputusan pendanaan dalam penelitian diukur dengan rasio dengan Debt to Asset Ratio (DAR) yang menunjukkan perbandingan antara total utang dengan total aktiva. Perusahaan Jasa Konstruksi yang terdaftar di Bursa Efek Indonesia memiliki rata-rata DER sebesar 0,62 kali yang mana masih dinilai sangat aman, karena dibawah batas angka 4 kali sesuai ketentuan perbandingan antara utang dan modal menurut PMK No. 169/PMK.010/2015. Sejalan dengan hasil penelitian, bahwa keputusan pendanaan yang dilakukan oleh perusahaan direspon positif oleh investor. Investor meyakini bahwa keputusan pendanaan memberikan informasi yang menguntungkan bagi pertumbuhan laba maupun pertumbuhan perusahaan. Dengan kondisi tersebut, tidak keliru bahwa kinerja keuangan yang dalam hal ini menggunakan tingkat profitabilitas tidak menjadi sumber pertimbangan investor. Kinerja keuangan dalam penelitian ini menggunakan rasio profitabilitas yaitu Return on Equity Ratio (ROE). Rasio ini mengukur seberapa laba bersih yang dihasilkan oleh modal sendiri. 
Investor lebih menyukai penggunaan utang yang lebih besar daripada pendanaan melalui modal sendiri.

Adapun, keaktifan perusahaan dalam interaksinya terhadap masyarakat menjadi faktor yang perlu dipertimbangkan saat ini yaitu melalui aktifitas CSR. Namun, saat ini aktifitas CSR masih terbilang muda bagi perusahan-perusahaan di Indonesia. Selain tuntutan finansial yang tidak kecil, keseriusan perusahaan dalam menjabarkan kegiatannya melalui pengungkapan CSR pada laporan tahunan sangatlah penting. Seperti diketahui bahwa terdapat dua jenis ungkapan dalam laporan keuangan yang telah ditetapkan oleh badan yang memiliki otoritas di pasar modal. Yang pertama adalah ungkapan wajib (mandatory disclosure), yaitu informasi yang harus diungkapkan oleh emiten yang diatur oleh peraturan pasar modal di suatu negara. Sedangkan yang kedua adalah ungkapan sukarela (voluntary disclosure), yaitu ungkapan yang dilakukan secara sukarela oleh perusahaan tanpa diharuskan oleh standar yang ada. Dalam penelitian ini, pengidentifikasian hal-hal yang berkaitan dengan pelaporan sosial untuk mengetahui apakah perusahaan melaksanakan mandatory disclosure berdasarkan standar GRI ( Global Reporting Intiative). GRI (Global Reporting Intiative) merupakan sebuah jaringan berbasis organisasi yang telah mempelopori perkembangan dunia, paling banyak menggunakan kerangka laporan keberlanjutan dan berkomitmen untuk terusmenerus melakukan perbaikkan dan penerapan di seluruh dunia. Tiga fokus pengungkapan yang harus dilakukan perusahaan dengan ketentuan GRI , antara lain: Indikator Kinerja Ekonomi (economic performance indicator), terdiri dari 9 item; Indikator Kinerja Lingkungan (environment performance indicator), terdiri dari 34 item.; dan Indikator Kinerja Sosial (social performance indicator), terdiri dari 48 item.

Sesuai dengan proses identifikasi, maka dapat diketahui pengungkapan tanggung jawab sosial berdasarkan GRI sangatlah rendah dengan angka rata-rata sebesar 0,0532 atau kurang lebih hanya ada 5 item rata-rata aktivitas CSR yang terungkap sesuai GRI pada laporan tahunan. Angka tertinggi yaitu 0,38 atau 35 item aktivitas CSR yang terungkap sesuai GRI pada laporan tahunan, sedangkan terendah yaitu 0,01 atau 1 item aktivitas CSR yang terungkap sesuai GRI pada laporan tahunan. Hal tersebut bukan berarti perusahaanperusahaan tidak melakukan pengungkapan tanggung jawab sosial, namun berdasarkan hasil identifikasi bahwa beberapa perusahaan telah melakukan pengungkapan terkait kinerja ekonomi, lingkungan maupun sosial. Pengungkapan tanggung jawab sosial dapat disimpulkan terus meningkat selama lima tahun terakhir, hanya saja pengungkapan tanggung jawab sosial yang diungkapkan perusahaan merupakan informasi yang sifatnya sukarela (voluntary disclosure) atau pengungkapan yang dilakukan perusahaan bersifat bebas tidak menyesuaikan dengan aturan pengungkapan yang telah ditetapkan oleh badan yang memiliki otoritas di pasar modal.

\section{PENUTUP}

\section{Kesimpulan}

1. Hasil uji hipotesis $\mathrm{H}_{01}$ pada 6 sampel penelitian dengan kode: ADRO, BSDE, KLBF, PTPP, SMRA, dan WIKA selama periode penelitian, menunjukkan bahwa sinyal harga dari indikator MACD tidak berbeda dengan close price terdekat saham JII tahun 2016 s.d. 2018, sehingga sinyal beli dan sinyal jual yang dihasilkan oleh indikator MACD akurat dan dapat digunakan untuk mengambil keputusan berinvestasi di pasar modal.

2. Hasil uji hipotesis $\mathrm{H}_{02}$ menunjukkan bahwa sinyal harga dari indikator RSI tidak berbeda dengan close price terdekat saham JII tahun 2016 s.d. 2018, sehingga sinyal beli dan sinyal jual yang dihasilkan oleh indikator RSI akurat dan dapat digunakan untuk mengambil keputusan berinvestasi di pasar modal.

3. Hasil uji hipotesis $\mathrm{H}_{03}$ menunjukkan bahwa tidak terdapat perbedaan antara sinyal harga yang dihasilkan 2 indikator, sehingga pada obyek dan periode yang sama yaitu saham JII tahun 2016 s.d. 2018, indikator MACD dan RSI menghasilkan keputusan investasi (sinyal beli dan jual) yang sama secara statistik. Indikator MACD dan RSI sama-sama dapat memberikan jawaban waktu terbaik untuk membeli atau menjual suatu saham.

\section{Saran \\ Bagi Pihak Lembaga}

Bagi lembaga terkait penting untuk memperhatikan komposisi kepemilikan saham, mengelola sebaik mungkin keputusan pendanaan, memperbaiki kinerja keuangan perusahaan dengan berbagai ukuran kinerja, serta perlu ditingkatkan pengungkapan CSR sesuai dengan data GRI.

\section{Bagi Peneliti Selanjutnya}

Peneliti selanjutnya diharapkan untuk mengkaji lebih banyak sumber maupun referensi yang terkait dengan struktur kepemilikan saham, keputusan pendanaan, CSR, kinerja keuangan dan 
nilai perusahaan pada perusahaan yang sama atau sejenis dengan skope yang lebih besar agar hasil penelitiannya dapat lebih baik dan lebih lengkap lagi.

\section{DAFTAR PUSTAKA}

Abdolkhani, Hakim dan Jalali, Reza. 2013. Effect of Managerial Ownership Concentrated on Firm Return and Value: Evidence from Iran Stock Market. International Journal of Academic Research in Accounting, Finance and Management Sciences Vol. 3, No. 1, January 2013, pp. 46-51.

Aggarwal, D dan Padhan, P.C. 2017. Impact of Capital Structure on Firm Value: Evidence from Indian Hospitality Industry. Theoretical Economics Letter, 7, 982 1000.

Bowen, Howard R. 1953. Social Responsibility of The Businessman. Harper and Brother. New York.

Dian, Fahrur dan Lidyah, Rika. 2013. Pengaruh Corporate Social Responsibility, Kepemilikan Manajerial dan Kepemilikan Institusional terhadap Nilai Perusahaan Tambang Batu Bara yang Terdaftar di BEI. Jurnal Akuntansi STIE MDP.

Fahmi, Irham. 2011. Analisa Laporan Keuangan. Bandung: Alfabeta.

Fama, Eugene and Frech, Kenneth R. 1998. Taxes, Financing Decisions, and Firm Value. The Journal of Finance, Vol. 53 (3): 819 - 843.

Freeman, R. Edward dan David L. Reed. 1983. Stockholders and Stakeholders: A New Perspective on Corporate Governance. California Management Review. Vol. 25. No. 3. hlm. 88 - 106.

Gujarati, Damodar. 2003. Ekonometri Dasar. Jakarta: Erlangga.

Hadi, Nor. 2011. Corporate Social Responsibility. Yogyakarta : Graha Ilmu.

Hardinis, M. 2019. Capital Structure and Firm Size on Firm Value Moderated by Profitability. International Journal of Economics and Business Administration Volume VII, Issue 1, 2019, pp. $174-191$.

Jensen, M. dan Mackeling, W. 1976. Theory of the Firm: Managerial Behaviour, Agency Cost and Ownership Structure. Journal of Financial Economics 3, pp. 305 - 360.

Keown, Arthur J, dkk. 2010. Dasar - dasar Manajemen Keuangan. Jakarta: Salemba Empat.

Kodongo, Odongo, dkk. 2014. Capital Structure, Profitability and Firm Value: Panel
Evidence of Listed Firms in Kenya. MPRA Paper No. 57116, 6 July 2014.

Manurung, Shinta D., dkk. 2014. The Influence of Capital Structure on Profitability and Firm Value. Jurnal Administrasi Bisnis (JAB), Vol. 7, No.2, Januari 2014.

Paminto, Ardi, dkk. 2016. The Effect of Capital Structure, Firm Growth and Dividend Policy on Profitability and Firm Value of the Oil Palm Plantation Companies in Indonesia. European Journal of Business and Management, Vol. 8, No. 33, pp. 123 134.

Ridhawati, Rini. 2014. Analisis Kinerja Keuangan Menggunakan Economic Value Added (EVA) dan Market Value Added (MVA). Jurnal Ilmiah Mahasiswa FEB.

Sabrin, dkk. 2016. The Effect of Profitability on Firm Value in Manufacturing Company at Indonesia Stock Exchange. The International Journal of Engineering and Science, Vol. 5, Issue 10, pp. $81-89$.

Sugiyono. 2017. Metode Penelitian Pendidikan Pendekatan Kuantitatif, Kualitatif dan $R \& D$. Bandung: Alfabeta.

Thoifah, I'anatut. 2015. Statistika Pendidikan dan Metode Penelitian Kuantitatif. Malang: Madani.

Ulum, Ihyaul. 2009. Intellectual Capital: Konsep dan Kajian Empiris. Yogyakarta: Graha Ilmu.

\section{Profil Penulis}

1. Harsana, S.T., M.M, Alumni Program Magister Manajemen Fakultas Ekonomi dan Bisnis ULM.

Email: harsana@gmail.com

2. Dr. Meina Wulansari Yusniar, S.E., M.Si, Dosen Program Magister Manajemen Fakultas Ekonomi dan Bisnis ULM.

Email: meina_unlam@yahoo.co.id

3. Asrid Juniar, S.E., M.M, Dosen Manajemen Fakultas Ekonomi dan Bisnis ULM.

Email: asrid1978@yahoo.com 